\title{
What's an architectural journal for?
}

As well as being sent to our regular subscribers, this issue of arq has also been sent to practices, libraries and individuals worldwide whom we want to encourage to subscribe. So this 'leader' seems a good moment to reflect on what an architectural journal is for.

In the UK, in the 196os and 1970s, The Architects' Journal was recast in the scientific mode of the time. Every issue contained lengthy building studies which were, in effect, documented as research experiments for the advancement of the discipline. The journal also contained the latest in materials, environmental design and education. The AJ's sibling at London's Architectural Press, the Architectural Review, regularly interspersed its building studies with debates around history and theory. These journals were focussed on presenting the latest work clearly, demonstrating and debating the 'state of the art'. Today's popular architectural media rarely have comparable ambitions. They often prefer to be providers of news and comment. In many, the length of the building studies has reduced, the drawings are printed at a scale too small to read and there is little serious detail on the latest research which informs architectural production and debate. There are, of course, notable exceptions but weekly and monthly production schedules rarely encourage the long view.

This is where arq comes in. Run by a team of academics who aim to publish the latest serious work in design, criticism, urbanism, history, theory, environmental design, materials, education and more, arq is intended to bridge practice and academia, documenting the best outcomes of research - in the broadest sense - from designers, writers and scientists wherever they are based. Our quarterly schedule and academic review process means that the contents are rigorously tested.

In this issue, Stephen Walker evaluates the body of work produced to date by the young office of Mole Architects, exploring themes which arise from their projects. Laura Hourston Hanks reviews Reiach and Hall Architects' Pier Arts Centre in Stromness, completed in 2007, exploring how its 'memoryscapes' operate on local and global scales. Turning to recent history, Harry Charrington - once an employee of the Aalto atelier - documents conversations with architects who worked on some of the office's most significant projects. A different sort of knowledge from a different time is investigated by Alexander Wragge-Morley, who examines Robert Hooke and Christopher Wren's interest in ancient buildings. Robert Atkinson, meanwhile, describes an innovative pre-University architecture programme that he has developed at Richmond-upon-Thames College in London.

If you're not already persuaded of the merits of arq, we hope the contents of this issue might tempt you to subscribe (a subscription form is printed on the following page). As well as issues like this which present a range of work, we are also planning thematic issues in association with members of our international editorial board and in conjunction with conferences and events. Forthcoming issues will address architecture and landscape, and architecture and site.

Architectural ideas - be they in design or in other areas of research - are rarely formed by drawing on just one source or another; they stem from a rich mix of ideas and inputs and a developed appreciation of architectural culture. We are confident that arq will help you to deepen and broaden that mix and welcome suggestions about how we can make the journal more relevant to your interests and needs. 


\section{architectural research quarterly}

\section{Subscribe now for 2011}

Innovative in conception, unique in breadth and generously illustrated, this pace-setting quarterly publication from Cambridge University Press links, on a global scale, the worlds of architectural practice and research. arq regularly includes extensive peer-reviewed sections on design, history, theory, construction, environmental design, information technology and practice - as well as structures, urbanism and documents. These are supplemented by letters, reports, reviews, a directory of specialist research centers and consultancies and an annual index. Each issue opens with a leader and closes with insight, a personal end-piece. In its ten year history, arq has published work from all over the world: from Chile to Sweden and from Japan to the Netherlands - with a strong representation from the United Kingdom and United States. arq, like architecture itself, is all-embracing and written by and for both practitioners and academics. It provides an outlet for all those who wish to disseminate their work to an international audience.
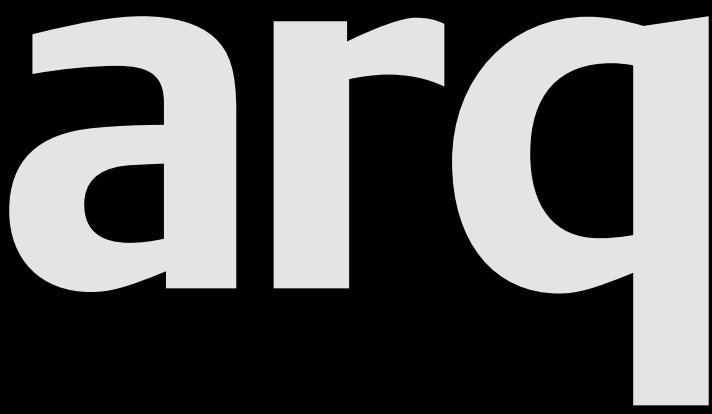

Please enter my subscription to

arq: architectural research quarterly, volume 15, 2011

$E_{207} / \$ 349$ institutions print and electronic
$E_{32} / \$ 54$ students print only
$E_{44} / \$ 68$ individuals print only

EU residents only. VAT may be payable at your local rate if not registered.

Our VAT registration number: GB 214141614 If registered, your VAT registration no:

Total subscription payment $€ / \$$

Eu residents only, if not registered add VAT at appropriate rate

Canadian residents, add 7\% GST \$

Total $\mathbf{E} / \mathbf{S}$

Name

Address

\section{Payment enclosed}

Cheque in sterling or US dollars

(payable to Cambridge University Press)

| Credit Card - VISA | MasterCard | American Express (delete where applicable)

Card no

Expiry date

Signature

Photocopy this page and send your order to: Journals Customer Services, Cambridge University Press, The Edinburgh Building,

Cambridge, CB2 8RU, UK

$\mathrm{T}+44(0) 1223326070$

$\mathrm{F}+44(0) 1223315052$

E journals@cambridge.org

or in USA, Canada and Mexico send to:

Cambridge University Press, 32 Avenue of the

Americas, New York NY 10013-2473, USA

T (914) 9379600

F (914) 9374712

E journals_subscriptions@cup.org 